\title{
$\gamma$-secretase gene mutations link acne inversa (flexural, scarring acne) with Alzheimer's disease
}

\author{
A Anstey \\ Consultant Dermatologist, Aneurin Bevan Health Board, Wales, UK
}

TITLE $\gamma$-secretase gene mutations in familial acne inversa

AUTHORS Wang B, Yang W, Wen W et al.

\section{JOURNAL Science 2010; 330:1065. doi:I0.I I26/science.II96284}

DECLARATION OF INTERESTS The author has no financial conflicts to declare. He does, however, have potential academic conflicts, having set up a clinical genetics study on acne inversa with the aim of identifying the gene responsible for the familial variant of this condition.

\author{
Correspondence to A Anstey, \\ Royal Gwent Hospital, Cardiff Road, \\ Newport, Gwent NP4 OTY, UK \\ tel. $+44(0) 1633234450$ \\ e-mail alex.anstey@wales.nhs.uk
}

\section{SUMMARY}

This paper has caused a stir in academic circles for dermatology, neurology, care of the elderly and neuropsychiatry. Acne inversa (Al, previously known as 'hidradenitis suppurativa'), a common and disabling variant of acne has been recognised for decades as being caused by an occlusion of hair follicles. It is characterised by painful abscesses, sinuses and scars in the axillae and groin. At its worst, Al blights patients' lives, making daily activities uncomfortable and sexual relationships unthinkable. The onset of $\mathrm{Al}$ is post puberty and may be familial or sporadic. Using combined genome-wide linkage scan and haplotype analysis in six Han Chinese families, Baoxi Wang and colleagues reveal that mutations in PSENI, PSENEN and NCSTN (the genes encoding the proteins presenilin I, presenilin enhancer 2 and nicastrin respectively) cause acne inversa. Clinical phenotypegenotype studies revealed that all of the mutations in these three genes segregated with disease with complete penetrance. Furthermore, all of the mutations were predicted to inactivate protein function.

How do six different mutations in three different genes cause Al? The answer lies in the relationship between the three genes; all are elements encoding the $\gamma$-secretase enzyme. $\gamma$-secretase cleaves type I transmembrane proteins such as amyloid precursor protein and Notch; a deficiency of this enzyme in mice leads to an occlusion of hair follicles, the initiating pathogenetic event in Al. ${ }^{1,2}$ It has previously been established that an inactivation of Notch-I, a gene that encodes a transmembrane protein, Notch-I, which is cleaved by $\gamma$-secretase, also produces follicular occlusion in mice. ${ }^{3}$ Thus, disruption of the $\gamma$-secretaseNotch pathway appears to play a central role in the pathogenesis of familial Al.

\section{OPINION}

Why should genetic research on the familial form of an acne variant be of interest to general physicians? Firstly, $\mathrm{Al}$ is much more common than is widely appreciated and is seen frequently, but perhaps not recognised, by general physicians (the previous term, 'hidradenitis suppurativa', acted as a barrier to diagnosis by being both unpronounceable and meaningless to most of us). Secondly, the discovery of a genetic basis for the familial variant of $\mathrm{Al}$ now offers the prospect of a programme of research leading to an understanding of the pathogenesis of all cases of $\mathrm{Al}$, not just the familial variant.

Finally, and perhaps of greatest interest, dysfunction in $\gamma$-secretase has also been implicated in Alzheimer's disease. ${ }^{4,5} \mathrm{~A}$ better understanding of how abnormalities in $\gamma$-secretase result in two such disparate clinical phenotypes may yield novel approaches to treatment for both conditions. Thus, general physicians should follow the progress of this research; clinical therapeutic translation is a realistic hope and expectation.

\section{REFERENCES}

I Xia X, Qian S, Soriano S et al. Loss of presenilin I is associated with enhanced $\beta$-catenin signalling and skin tumorigenesis. Proc Natl Acad Sci USA 2001; 98: 10863-8. doi: 10.1073/pnas. I91284198

$2 \mathrm{Li} \mathrm{T,Wen} \mathrm{H,} \mathrm{Brayton} \mathrm{C} \mathrm{et} \mathrm{al.} \mathrm{Epidermal} \mathrm{growth} \mathrm{factor} \mathrm{receptor}$ and notch pathways partyicipate in the tumor suppressor function of gamma-secretase. J Biol Chem 2007; 282:32264-73. doi:I0.1074/jbc.M703649200

3 Nicolas $M$, Wolfer A, Raj $\mathrm{K}$ et al. Notch-I functions as a tumor suppressor in mouse skin. Nat Genet 2003;33:416-2I.doi:I0.1038/ ngl099

4 Shen J, Kelleher RJ.The presenilin hypothesis of Alzheimer's disease. Evidence for a loss-of-function pathogenetic mechanism. Proc Natl Acad Sci USA 2007; 104:403-9. doi:10.1073/pnas.0608332104

5 Hardy J, Selkoe DJ.The amyloid hypothesis of Alzheimer's disease: progress and problems on the road to therapeutics. Science 2002; 297:353-6. doi:10.1126/science.1072994 